"The market reactions to share repurchase announcements on the JSE: an event study"

\begin{tabular}{|c|c|c|}
\hline AUTHORS & $\begin{array}{l}\text { Kiran Punwasi } \\
\text { Pradeep Brijlal }\end{array}$ & \\
\hline ARTICLE INFO & \multicolumn{2}{|c|}{$\begin{array}{l}\text { Kiran Punwasi and Pradeep Brijlal (2016). The market reactions to share } \\
\text { repurchase announcements on the JSE: an event study. Investment Management } \\
\text { and Financial Innovations, } 13(1-1), 191-205 \text {. doi:10.21511/imfi.13(1-1).2016.06 }\end{array}$} \\
\hline DOI & \multicolumn{2}{|c|}{ http://dx.doi.org/10.21511/imfi.13(1-1).2016.06 } \\
\hline RELEASED ON & \multicolumn{2}{|l|}{ Friday, 08 April 2016} \\
\hline JOURNAL & \multicolumn{2}{|c|}{ "Investment Management and Financial Innovations" } \\
\hline FOUNDER & \multicolumn{2}{|c|}{ LLC "Consulting Publishing Company "Business Perspectives" } \\
\hline & & $\begin{array}{l}= \pm= \\
= \pm=\end{array}$ \\
\hline NUMBER OF REFERENCES & NUMBER OF FIGURES & NUMBER OF TABLES \\
\hline 0 & 0 & 0 \\
\hline
\end{tabular}

(C) The author(s) 2023. This publication is an open access article. 


\title{
The market reactions to share repurchase announcements on the JSE: an event study
}

\begin{abstract}
This study examines the market reactions to share repurchase announcements made by companies listed on the Johannesburg Stock Exchange from the years 2003 to 2012. The authors use an event study methodology and the Capital Asset Pricing Model to determine if there was an announcement effect when a share repurchase announcement is made. The analyses reveal that consistent with signalling theory and the announcement effect, share repurchase announcements are associated with positive abnormal returns. The average abnormal return and cumulative average abnormal return noted was $0.46 \%$ and $3.81 \%$, respectively, for the event period $(\mathrm{t}-20, \mathrm{t}+20)$. There was an observable trend of declining share prices before the share repurchase announcement. The authors also found no significant evidence that repurchasing firms have market timing ability when executing a share repurchase announcement. From a value investor's perspective, a share repurchase program conveys a very strong signal of a healthy company.
\end{abstract}

Keywords: market reaction, share repurchase announcement, average abnormal returns, cumulative average abnormal returns.

JEL Classification: G00.

\section{Introduction}

Companies that accumulate cash quickly may find it difficult to reinvest the cash at attractive rates of returns. Such companies may also be faced with the difficult task of finding new investment opportunities which benefit its shareholders. Bhana (2007) states that when companies plan their allocation of any surplus capital resources, they are faced with two major options; they may decide to invest the funds in order to advance their business goals, which include capital expenditure, retaining funds for working capital or engaging in acquisitions and mergers. The second option is that they may decide on returning cash to shareholders in the form of dividends, debt repayment or share repurchases. In this study, we focus on share repurchases and its impact on share prices.

A share repurchase allows a company to reinvest in itself by increasing the proportion of shares that it owns thereby reducing the number of its shares in the market. Share repurchases have become an important financial policy for listed companies for the past twenty years in the United States (Bhana, 2007). The reason for the increase in this form of activity is motivated by the use of open market repurchases programs, where no additional premium is paid to the current share price when repurchasing a company's shares. Both Skinner's (2008) research into the US markets and Von Eije and Megginson's (2008) research into the European markets indicate a trend that share repurchases are becoming a

(C) Kiran Punwasi, Pradeep Brijlal, 2016.

Mr. Kiran Punwasi, Gordon Institute of Business Science, University of Pretoria, South Africa.

Dr Pradeep Brijlal, School of Business and Finance, University of the Western Cape, South Africa. dominant method of replacing dividends and distributing corporate cash flows to shareholders.

In the context of the economic climate, Grullon and Ikenberry (2000) found that share repurchases will likely remain the dominant transaction in the future as more countries adopt enabling regulations such as relaxed tax legislations and corporate laws. Grullon and Ikenberry (2000) state that other factors affecting share repurchase program activity include the level of market prices and the underlying condition of the economy, citing that when share prices fall announcements of share repurchases rise.

Literature reveals that other motivation for a share repurchase is that managers seem to believe that the shares are undervalued, such as Vermaelen (1981), Stephens and Weisbach (1998), Ikenberry, Lakonishok and Vermaelen (2000), Grullon and Ikenberry (2000), Bhana (2007), Lo, Wang, and Yeh (2008), Skinner (2008) and Von Eije and Megginson (2008). However, De Ridder (2009) points out that the knowledge of how firms actually execute repurchases and impact of repurchases on the market have not yet been fully explored due to data constraints such as access to credible execution data and models for analysis purposes.

Studies on share repurchases have long been practised in the developed markets, such as Ikenberry and Vermaelen (1996) and Mishra, Racine and Schmidt (2010). However, due to the operating nature of these developed markets, their size, the differences in the rules and regulations that govern such markets and the maturity of the stock exchanges, their findings may not be applicable to the developing markets such as South Africa. In the South African context studies have either been conducted soon after the Johannesburg Securities Exchange (JSE) officially allowed share repurchases 
in October 2000 or were not conducted over a long enough period to yield any reliable results. Due to the limited availability of studies in this area in South Africa, this study adds to the literature on share repurchases.

Our study, thus, aims to examine the market reaction surrounding the announcements of share repurchases by listed companies on the JSE in order to establish whether there is an "announcement effect", which may react in one of three ways:

1. positive reaction: characterized by an increase in the share price;

2. negative reaction: characterized by a decrease in the share price; or

3. no reaction: characterized by not responding at all.

This study utilized a data set of share purchase announcements and share prices covering the period from January 2003 to August 2012. Previous studies conducted in the field of share repurchases on the JSE employed shorter periods (i.e., from 6 months to 5 years). This study used a total of 9 years and 8 months of data under the assumption that a longer period will yield more reliable and conclusive results.

\section{Literature review}

Firms buy back their own shares for various reasons. Some of the reasons found in the literature include managerial intentions to signal to the market that the shares are undervalued, to ward of potential takeover raiders, to distribute cash through repurchase instead of dividend payments, to use repurchased shares to settle outstanding options and convertible securities to avoid dilution, to distribute excess cash where there is no investment opportunity, and to adjust financial leverage (Lee et al., 2010). This study focuses on the market reaction to share repurchases concentrating on three common threads for repurchasing shares, namely, signalling theory, longterm stock performance and market timing.

The signalling theory can be regarded as management's "signal" to the market that the current market price of the share is undervalued. This presupposes the existence of information asymmetry between management and investors. The greater the degree to assess the value of a firm, the more likely it is that information asymmetry may obscure the true value of a firm and hence it is unlikely that the firm may be undervalued. The long term stock performance following a share repurchase announcement determines if firms experience positive abnormal returns afterwards and if firms repurchase their shares after a series of consecutive price declines. Market timing of share repurchases determines if firms can re-acquire shares at a lower price. The following sections will provide a brief discussion on each of the three common threads that have been described above.

\subsection{Market undervaluation as a motive for share} repurchases. Grullon and Ikenberry (2000) noted that researchers tend to study the markets in search of an explanation that describes some trend or activity that can explain a phenomena. The growing trend of share repurchases is regarded as a new phenomenon and researchers such as Grullon and Ikenberry (2000), Dittmar (2000), Dobbs and Rehm (2005) and Lee et al. (2010) offer explanations to this phenomena stating that markets respond to announcements of share repurchases because they offer new information, sometimes called a "signal" about a company's future and, hence, its share price.

Grullon and Ikenberry (2000) offer two different versions to the "signalling" explanation. The first version states that repurchases are intended to convey a firm's expectation of future increases in earnings and cash flow. This is also known as a positive signal, indicating that management has correctly forecasted future cash flow and does not need the excess cash to cover future commitments such as capital expenditures or interest payments.

The second version is that management is not attempting to convey new information to the market about a company's future and, hence, its share price, but is instead expressing its disagreement on how the market is pricing their current performance. Grullon and Ikenberry's study is based on investors making rationale decisions; therefore, they do not allow feelings/emotions to cloud their decision. In the same light, they opine that managers will buy back shares when they feel it is too low. This is management's view that the share is undervalued. Isa, Ghani and Lee (2011) provide support to this argument by stating that information asymmetry (where managers within the firm have better information than outside investors), which in the context of share repurchases, means that firms will buy back shares when they perceive or observe that the market is not providing the correct value to the firm.

Jiang and Koller (2011) offer a different explanation to "signalling" theory stating that a negative signal, i.e., management's view that the share is undervalued, could indicate a failure of management to find sufficient value-creating investment opportunities. However, studies on share repurchase motives by Asquith and Mullins (1986), Ikenberry and Vermaelen (1996), Dittmar (2000), Lee and Rui (2007), Bhana (2007), De Ridder (2009) and Lee et al. (2010) indicate that there may be ulterior motives behind the decisions to repurchase shares, such as: 
tax benefits, distributing excess cash, and adjusting capital structure. Companies may also repurchase their shares to reduce the supply of their shares in the market or to eliminate any threats of unwanted takeover attempts by corporate raiders when the shares are traded at a low value. Lee et al. (2010) state that if the share is undervalued, potential raiders may also be attracted to take over the company. Management may then decide to repurchase shares so that the share price will adjust upwards to the correct level for the benefit of shareholders or to dismay the raider.

Lee et al. (2010) further argue that signalling information to correct the share valuation and evade outside takeover attempts of undervalued firms is more apparent under conditions of strong market monitoring circumstances. If there is no market monitoring, management may not be under pressure to release private information and share price may not respond to actions such as repurchase announcements. In this instance, the raider may also not benefit from taking over the undervalued firm since share price may not increase in the absence of market monitoring.

When announcing a share repurchase program, Lee and Rui (2007) note that managers often make statements that their share is "undervalued" or a "good buy" or "prices don't reflect the true value of the firm". The authors support the study by Ikenberry et al. (2000), who found that over a four year period on perceived undervalued shares there were excess returns of $12.14 \%$. In an attempt to focus on mispricing, Ikenberry et al. (2000) also considered the book-to-market ratio of companies when they announced their repurchase programs. Companies with high book-to-market ratios are often viewed as "value" stocks and in such cases, perceieved undervaluation is likely to be the primary factor in the decision to repurchase shares. For stocks with low book-to-market ratios, which are known as "growth" stocks, undervaluation seems less likely to be the dominant motivating factor.

Share repurchase study by Isa et al. (2011) using an event study on the Malaysian Stock Exchange of 149 firms over the period 2001 to 2005 showed a positive market reaction to the actual repurchase of shares. The authors found that the pre-event abnormal returns and the event days abnormal returns clearly suggest the existence of a signalling effect of the repurchase. They also found that the signalling effect is larger for small firms compared to larger ones.

Based on the review of the literature above, undervaluation can be viewed as a dominant motive to executing a share repurchase corporate action in any given market and not just in developed markets. However, when firms make repurchase announcements, the market expects that they will follow the repurchase program and experience a more desirable share performance following the announcement date (Chang et al., 2010).

1.2. Long-term performance of open-market repurchase programs. Accessing long-term abnormal price performance can be very sensitive to performance benchmarks. A common method among the literature suggests a simple buy-and-hold return (BHR) should be used to measure long-run abnormal stock returns. Buy-and-hold abnormal returns (BHARs) are calculated relative to matched control firms based on both firm size and book-tomarket value (BTMV).

Vermaelen's (1981) initial study of 243 open market announcements finds that firms have been experiencing negative abnormal stock price performance prior to the open market repurchase. In the three months preceeding the repurchase, their share prices have underperformed the market by about $7 \%$. The repurchase of shares produces a gain of little more than $3 \%$, but prices retreat about $1 \%$ during the following three months, resulting in an apparent gain of $2 \%$.

Ikenberry et al. (2000) re-examined long term market performance using a three factor model and a sample of 1,060 Canadian firms. The findings demonstrated abnormal performance over the three year period after the share repurchase announcement and excess returns to be $0.587 \%$ per month were achieved (7\% per year). For growth firms, excess returns of about $3.3 \%$ per year were achieved over the three-year period following the announcement while value firms earned excess of $9.1 \%$ per year.

In another study by Chan, Ikenberry and Lee (2004), the authors examined long-horizon returns of over 4,000 open market share repurchase programs announced by US firms from 1980 to 1996, reporting evidence of abnormal returns. The study also found some evidence of excess performance by growth shares. The authors also found evidence of higher long-run abnormal returns when companies actually repurchase shares in the first year of the repurchase program, particularly for value shares.

A study of repurchase programs by firms that are listed on the New York Stock Exchange (NYSE), the American Stock Exchange (the "AMEX") and the NAS-DAQ was conducted by Yook (2010), with a sample that consisted of 9,551 repurchase programs that were announced between the period 1994 and 2007. The author found strong evidence of significant abnormal long-term performance of 
infrequent repurchasers who actually repurchase shares during the first four quarters following their announcements versus frequent repurchasers.

An analysis by Bhana (2007) of long-term performance of South African firms listed on the JSE during the period from October 2000 to March 2003, involved in 117 open market share repurchases, has shown that despite managers' frequent claims of undervaluation when announcing share repurchases, the return in the immediate days following the announcement is relatively small. This suggests that either the managers are being overly optimistic relative to the market about the firm's value or alternatively the market is wrong in responding and is, thus, underreacting to the repurchase signal. The possibility also exists that the market is slow in responding to the undervaluation signal contained in the repurchase announcements. The author found that using the buy-and-hold strategy, the three-year abnormal returns following the announcement was $14.35 \%$. Companies with high book-to-market ratios that announce repurchase programs provided a three-year abnormal return of $32.78 \%$.

1.3. Timing ability when executing share repurchase programs. Brockman and Chung's (2001) study of the bid-ask spread analyzed more than 5,000 share repurchases in 181 different firms on the Hong Kong Stock Exchange between the years 1992 to 1999 . Their findings indicate that repurchasing firms have market timing ability. Furthermore, they identified the important determinants of this market timing ability to be short-term interest rate, the firm's cash flow and the frequency of share repurchases.

Zhang (2005) conducted a study on repurchasing firms on the Hong Kong Stock Exchange from the period September 1993 to August 1997, analyzing 135 firms and 800 repurchase events, stating that firms display market timing ability by repurchasing shares after a 20-day period of negative share price performance. Zhang (2005) also concluded that the market reacts more favorably to small and value firms when they make actual share repurchases.

Furthermore, Ginglinger and Hamon (2007) examined share repurchases for 352 firms in France from the period 2000 to 2002, finding that repurchasing firms have market timing ability; meaning that these firms repurchased shares at a price lower than that paid by other investors. Their evidence suggests that firms act against market trends, executing their repurchases to take advantage of falling prices. This finding reaffirms the importance of timing skills as the repurchase would be expected to occur on trading days when prices are falling and/or immediately after a fall in the price. Managers who exercise timing skills, would expect to observe price trends in the trading days after the announcement day.

In summary, the evidence suggests that firms not only time their repurchase program announcements, but also actual share repurchases to buy back their shares at favorable prices. In line with the above brief literature review, this study aims to examine the market reaction surrounding the announcement of share repurchases made by listed companies on the JSE of South Africa. By examining the market reaction we were able to establish whether there was an "announcement effect". This question was answered by examining the Average Abnormal Return (AAR) and the Cumulative Average Abnormal Return (CAAR) when a share repurchase announcement was made.

The following research questions have been proposed:

1. What type of abnormal returns is associated with share repurchase announcements on the JSE?

2. Is there a significant price effect in the preannouncement period?

The following hypotheses were tested:

$\mathrm{H}_{0}$ : There is no significant difference between the means of the AAR in the post-announcement period and pre-announcement period.

$\mathrm{H}_{1}$ : There is a significant difference between the means of the AAR in the post-announcement period and pre-announcement period.

3. Do firms display market timing ability when repurchasing their shares?

The following hypotheses were tested:

$\mathrm{H}_{0}$ : There is no significant difference in timing share repurchase announcements.

$\mathrm{H}_{1}$ : There is a significant difference in timing a share repurchase announcement.

\section{Research methodology}

The research method for this study was based on the event study methodology used by Zhang (2005), Chang et al. (2010), Lin et al. (2011) and Isa et al. (2011) in their research on the market reactions and open-market share repurchase announcements. Konchitchki and O'Leary (2011) describe an event study methodology as a theoretical framework based on the efficient markets theory, which states that the price of a share includes all relevant information that is available to the market. As a result, when share repurchase 
announcements are made by companies they provide the market with information that has already been factored into the share price.

Secondary data were sourced and analyzed from existing financial databases such as INET Bridge, BFA, the South African Reserve Bank, National Treasury and the JSE website. This study was quantitative in nature and covered the period from 2003 to 2012. The unit of analysis was the share price of JSE listed companies that made a share repurchase announcement within the test period.

The population of the study was all companies listed on the JSE between the years 2003 and 2012. This period was chosen for three reasons, namely:

1. This covers a period when firms were allowed to repurchase their shares. Blouin, Raedy, and Shackelford (2007) noted that firms needed time to adjust their payout policies of dividends to share repurchases following adjustments to tax reforms. Thus, this study chose 2003 as the start to the test period to allow for adjustments in payout policies.

2. The period of the study starts from where Bhana's (2007) study ended.

3. This period was chosen for convenience as the data for companies in the sample that performed a share repurchase was readily available from 2003 onwards.

Companies which were initially listed, but later delisted for whatever reason during this time period were exlcuded. This study, therefore, lends itself to survivorship bias. The focus was on the main board of the JSE and excluded companies listed on the Alternative Exchange (ALTX). This exclusion may not have a significant impact on the findings since the combined market capitalization of these companies is smaller relative to the rest of the sample (Lemmon and Zender, 2008).

Announcements on share re-purchases are made through the Stock Exchange News Service (SENS), an electronic notice board and information system designed to ensure that price-sensitive announcements can be received timeously by investors and analysts. The daily closing share prices for each of the companies in the sample was downloaded from the McGregor BFA database for the period January 2003 up to and including 31 August 2012.

A content search was conducted for all corporate actions relating to share repurchases. During the period from 1 January 2003 to 31 August 2012, a total of 264 announcements were made by 99 listed companies on the JSE relating to share repurchases. There were two types of share repurchase announcements that are tracked on the McGregor BFA database. The first is "specific" share purchase and the second is "general" share repurchase.

In a "specific" share repurchase the company repurchases its shares from specific or defined shareholders. In a "general" or "open market", share repurchase, the company repurchases its shares from the general market where the number of listed shares are then withdrawn. This study only focused on open-market or 'general' share repurchases.

Konchitchki and O'Leary (2011) state that an "event window" indicates the number of days before and after the announcement date over which the abnormal returns are accumulated. Zhang (2005) and Lin et al. (2011) used the market model and an event window of 41 trading days from 20 days before to 20 days after with day 0 being the event day. The market model to obtain abnormal returns that have been used by Isa et al. (2011) uses an event window that starts from 20 days before the announcement and 20 days after the announcement $(-20,+20)$ for 41 days. The event window in this study starts from 20 days before the announcement to 20 days after the announcement $(-20,+20)$. The repurchase announcement day was designated as "day 0", therefore, the event period was for 41 days.

To calculate the abnormal return using the event study methodology, the Capital Asset Pricing Model (CAPM) was used. The daily return per share is calculated using the following equations listed below which has been adapted from Miller and Ward (2011):

$R_{i t}=\frac{\left(P_{i t}-P_{i t-1}\right)}{P_{i t-1}}$,

where: $R_{i t}=$ daily return of the share $i$ on trading day $t$; $P_{i t}=$ closing price of the share $i$ on trading day $t$; $P_{i t-1}=$ closing price of the share $i$ on trading day $t-1$.

The model's parameters such as beta $(\beta)$ were estimated using the 60 monthly data returns against the All Share Index (ALSI), prior to the event day. The daily AR for each share on each event day was calculated as follows:

$A R_{i t}=R_{i t}-\beta_{i} R_{m t}$,

where: $A R_{i t}=$ abnormal return of the share $i$ on trading day $t ; R_{i t}=$ return on the share $i$ on trading day $t ; \beta_{i} R_{m t}=$ beta $*$ the return on the market on trading day $t$.

The abnormal returns were then averaged to obtain the daily AAR as follows:

$A A R_{t}=\frac{1}{n} \sum_{i=1}^{n} A R_{i t}$,

where $n=$ number of firms on trading day $t$. 
To estimate the CAAR surrounding the event day, a benchmark of $100 \%$ was set for the day before the announcement (t-1). The CAAR was calculated using a multiplicative model which combines the effect of two factors and calculates the product of the isolated effects of each factor. The calculation is as follows:

$$
C A A R_{t+1}=\left(1+C A A R_{t 0}\right) \times\left(1+A A R_{t 1}\right)-1 .
$$

The estimation period in this study was split into sub-windows which were defined to examine the AAR. Researchers using event studies in share repurchases have used a range for the sub-windows. Table 1 below shows related studies on share repurchases and some characteristics. Different researchers used different sub-windows in their analysis; although, there were some similarities and overlaps.

Table 1. Share repurchase related studies and some characteristics

\begin{tabular}{|c|c|c|c|c|c|}
\hline Author & Topic & Number of firms & Sample period & Number of sub-windows & List of sub-windows \\
\hline \multirow{3}{*}{ Zhang (2005) } & \multirow{3}{*}{$\begin{array}{l}\text { Share price performance following actual } \\
\text { share repurchases }\end{array}$} & \multirow{3}{*}{135} & \multirow{3}{*}{ 1993-1997 } & \multirow{3}{*}{3} & $(-20,-1)$ \\
\hline & & & & & $(0,2)$ \\
\hline & & & & & $(0,20)$ \\
\hline \multirow{4}{*}{$\begin{array}{l}\text { Chang et al. } \\
(2010)\end{array}$} & \multirow{4}{*}{$\begin{array}{l}\text { Does prior record matter in the wealth } \\
\text { effect of open-market share repurchase } \\
\text { announcements? }\end{array}$} & \multirow{4}{*}{1,741} & \multirow{4}{*}{$1986-2005$} & \multirow{4}{*}{4} & $(0,1)$ \\
\hline & & & & & $(0,3)$ \\
\hline & & & & & $(-1,2)$ \\
\hline & & & & & $(-2,2)$ \\
\hline \multirow{3}{*}{ Lee et al. (2010) } & \multirow{3}{*}{$\begin{array}{l}\text { An empirical analysis of European stock } \\
\text { repurchases }\end{array}$} & \multirow{3}{*}{512} & \multirow{3}{*}{$1990-2005$} & \multirow{3}{*}{3} & $(-1,0)$ \\
\hline & & & & & $(0,0)$ \\
\hline & & & & & $(-1,+1)$ \\
\hline \multirow{4}{*}{ Isa et al. (2011) } & \multirow{4}{*}{$\begin{array}{l}\text { Market reaction to actual share } \\
\text { repurchases in Malaysia }\end{array}$} & \multirow{4}{*}{149} & \multirow{4}{*}{$2001-2005$} & \multirow{4}{*}{4} & $(-20,-1)$ \\
\hline & & & & & $(0,2)$ \\
\hline & & & & & $(3,20)$ \\
\hline & & & & & $(-20,20)$ \\
\hline Lin et al. (2011) & $\begin{array}{l}\text { Stock repurchase announcements and } \\
\text { stock prices evidence from Taiwan }\end{array}$ & 413 & $2000-2008$ & 1 & $(100,300)$ \\
\hline
\end{tabular}

To determine the statistical significance of the price effect in the pre-announcement period, t-statistics were used to examine the AAR. The t-statistic for the AAR before the event (t-20) up to the day before the event (t-1) was calculated. The results were compared to the t-statistic for the AAR after the event $(t+1)$ up to the end of the event window $(t+20)$ to determine if there was a significant difference, using a $95 \%$ confidence interval.

This study used the following three sub-windows:

- ( $(\mathrm{t}-20, \mathrm{t}-1)-20$ days before the event to 1 day before the event;

- (t $0, t+2)$ - the event day plus 2 days after the event; and

- (t $0, t+20)$ - the event day plus 20 days after the event.

A one-sample $t$-test was used to compare the mean of the AAR in each sub-window to the known value, which was the population mean.

\section{Research results}

This section presents the findings of the research; the first part describes the initial sample to gain an understanding of the two different types of share repurchase announcements (specific and general), and the second part provides descriptive statistics of the final sample.

The study only focused on general (open market) share repurchase announcements. As a result, the initial sample of 264 share repurchase announcements has been reduced to 195 share repurchase announcements. A final sample of 167 share repurchase announcements made by 62 companies, free from unrelated events, was used in the final analysis. Table 2 below shows the proportion of announcements per sector per calendar year. The size of the repurchase is split between specific and general share repurchase.

Table 2. Total share repurchase announcements per sector per calendar year for the population

\begin{tabular}{|l|c|c|c|c|}
\hline \multicolumn{1}{|c|}{ Sector } & Year & Number of announcements & General & Specific \\
\hline Chemicals & 2003 & 1 & $2,269,984$ & 0 \\
\hline Construction \& materials & 2003 & 1 & $9,751,254$ & 0 \\
\hline Financial services & 2003 & 3 & $3,957,525$ & $4,036,431$ \\
\hline Industrial goods \& services & 2003 & 13 & $8,708,092$ & $12,818,331$ \\
\hline Investment instruments & 2003 & 5 & 0 & $346,995,327$ \\
\hline Media & 2003 & 2 & $2,870,008$ & 0 \\
\hline Real estate & 2003 & 1 & 271,450 & 0 \\
\hline
\end{tabular}


Table 2 (cont.). Total share repurchase announcements per sector per calendar year for the population

\begin{tabular}{|c|c|c|c|c|}
\hline Sector & Year & Number of announcements & General & Specific \\
\hline Retail & 2003 & 1 & 19,337 & 0 \\
\hline Technology & 2003 & 5 & $5,807,049$ & $7,599,638$ \\
\hline Travel \& leisure & 2003 & 2 & 11,670 & 0 \\
\hline Construction \& materials & 2004 & 1 & $10,219,548$ & 0 \\
\hline Debt & 2004 & 1 & 2,500 & 0 \\
\hline Financial services & 2004 & 6 & $31,893,704$ & 0 \\
\hline Industrial goods \& services & 2004 & 5 & $35,245,554$ & $8,958,956$ \\
\hline Insurance & 2004 & 3 & $7,446,627$ & $35,376,184$ \\
\hline Personal \& household goods & 2004 & 1 & 0 & $9,374,251$ \\
\hline Real estate & 2004 & 1 & 95,000 & 0 \\
\hline Banks & 2005 & 4 & $10,164,515$ & 0 \\
\hline Basic resources & 2005 & 2 & $1,850,000$ & 0 \\
\hline Chemicals & 2005 & 1 & 174 & 0 \\
\hline Financial services & 2005 & 3 & $5,123,166$ & 0 \\
\hline Industrial goods \& services & 2005 & 7 & $42,753,897$ & $12,564,726$ \\
\hline Insurance & 2005 & 8 & $422,077,803$ & 0 \\
\hline Investment instruments & 2005 & 1 & $4,512,667$ & 0 \\
\hline Media & 2005 & 1 & $7,119,825$ & 0 \\
\hline Personal \& household goods & 2005 & 7 & $3,626,973$ & $10,066,376$ \\
\hline Retail & 2005 & 2 & $91,388,559$ & 0 \\
\hline Telecommunications & 2005 & 2 & $12,086,920$ & 0 \\
\hline Banks & 2006 & 1 & $1,305,000$ & 0 \\
\hline Basic resources & 2006 & 4 & $33,487,214$ & $38,331,012$ \\
\hline Financial services & 2006 & 5 & $37,628,271$ & $21,540,000$ \\
\hline Food \& beverage & 2006 & 3 & $1,971,298$ & 0 \\
\hline Healthcare & 2006 & 3 & $130,312,734$ & 0 \\
\hline Industrial goods \& services & 2006 & 5 & $37,385,407$ & $37,691,443$ \\
\hline Insurance & 2006 & 3 & $85,884,600$ & 0 \\
\hline Investment instruments & 2006 & 3 & $8,064,000$ & 300,000 \\
\hline Oil \& gas & 2006 & 1 & 0 & $60,111,477$ \\
\hline Personal \& household goods & 2006 & 9 & $46,956,394$ & 0 \\
\hline Retail & 2006 & 3 & $38,654,400$ & 0 \\
\hline Telecommunications & 2006 & 1 & $3,506,619$ & 0 \\
\hline Travel \& leisure & 2006 & 1 & 427,855 & 0 \\
\hline Banks & 2007 & 1 & $6,370,888$ & 0 \\
\hline Basic resources & 2007 & 3 & $72,870,529$ & 0 \\
\hline Financial services & 2007 & 1 & $13,876,793$ & 0 \\
\hline Food \& beverage & 2007 & 2 & $5,575,513$ & 0 \\
\hline Industrial goods \& services & 2007 & 4 & $7,195,974$ & 68,771 \\
\hline Insurance & 2007 & 1 & $44,023,149$ & 0 \\
\hline Retail & 2007 & 3 & $21,630,199$ & 0 \\
\hline Telecommunications & 2007 & 2 & 83,128 & 0 \\
\hline Travel \& leisure & 2007 & 1 & 8,994 & 0 \\
\hline Banks & 2008 & 4 & $1,258,735$ & 0 \\
\hline Basic resources & 2008 & 3 & $237,025,800$ & 428,347 \\
\hline Chemicals & 2008 & 1 & $1,895,592$ & 0 \\
\hline Construction \& materials & 2008 & 4 & $55,360,362$ & $3,769,252$ \\
\hline Financial services & 2008 & 1 & $8,211,988$ & 0 \\
\hline Industrial goods \& services & 2008 & 1 & 0 & $6,922,314$ \\
\hline Insurance & 2008 & 1 & $26,362,870$ & 0 \\
\hline Oil \& gas & 2008 & 1 & 0 & $31,500,000$ \\
\hline Real estate & 2008 & 1 & $1,740,178$ & 0 \\
\hline Retail & 2008 & 2 & $15,020,000$ & 0 \\
\hline Technology & 2008 & 3 & 876,670 & 0 \\
\hline Telecommunications & 2008 & 1 & $7,627,206$ & 0 \\
\hline
\end{tabular}


Table 2 (cont.). Total share repurchase announcements per sector per calendar year for the population

\begin{tabular}{|c|c|c|c|c|}
\hline Sector & Year & Number of announcements & General & Specific \\
\hline Travel \& leisure & 2008 & 1 & 0 & 1 \\
\hline Basic resources & 2009 & 2 & 0 & $70,519,719$ \\
\hline Construction \& materials & 2009 & 1 & $14,046,443$ & 0 \\
\hline Consumer services & 2009 & 1 & $1,826,705$ & 0 \\
\hline Debt & 2009 & 1 & 100,000 & 0 \\
\hline Financial services & 2009 & 1 & $1,343,305$ & 0 \\
\hline Healthcare & 2009 & 3 & 0 & $475,265,611$ \\
\hline Industrial goods \& services & 2009 & 3 & $30,215,750$ & $45,607,175$ \\
\hline Insurance & 2009 & 2 & $45,734,584$ & 0 \\
\hline Real estate & 2009 & 1 & $4,991,335$ & 0 \\
\hline Retail & 2009 & 2 & $21,500,000$ & 5,674 \\
\hline Telecommunications & 2009 & 1 & 0 & $243,500,011$ \\
\hline Basic resources & 2010 & 2 & $2,049,573$ & 0 \\
\hline Construction \& materials & 2010 & 5 & $1,740,018$ & $51,600,000$ \\
\hline Financial services & 2010 & 2 & $3,287,171$ & 0 \\
\hline Food \& beverage & 2010 & 1 & 0 & 968,105 \\
\hline Healthcare & 2010 & 2 & 0 & $34,681,301$ \\
\hline Industrial goods \& services & 2010 & 3 & $2,123,775$ & $33,967,693$ \\
\hline Retail & 2010 & 2 & $46,079,832$ & 0 \\
\hline Technology & 2010 & 2 & $14,004,426$ & 0 \\
\hline Banks & 2011 & 1 & 0 & $9,949,367$ \\
\hline Basic resources & 2011 & 5 & $4,393,864$ & $5,458,930$ \\
\hline Construction \& materials & 2011 & 2 & 550,000 & 948,900 \\
\hline Food \& beverage & 2011 & 1 & $8,984,469$ & 0 \\
\hline Industrial goods \& services & 2011 & 9 & $6,195,218$ & $99,036,210$ \\
\hline Media & 2011 & 1 & $4,991,374$ & 0 \\
\hline Retail & 2011 & 5 & $16,354,311$ & 843 \\
\hline Technology & 2011 & 2 & 682,000 & $5,815,363$ \\
\hline Telecommunications & 2011 & 2 & 0 & $91,871,052$ \\
\hline Construction \& materials & 2012 & 2 & $22,085,788$ & 0 \\
\hline Consumer services & 2012 & 1 & 340,000 & 0 \\
\hline Financial services & 2012 & 3 & $7,705,774$ & 169,287 \\
\hline Industrial goods \& services & 2012 & 12 & $14,324,984$ & $1,424,780$ \\
\hline Investment instruments & 2012 & 2 & $9,000,000$ & $35,765,285$ \\
\hline Real estate & 2012 & 3 & $32,623,899$ & 0 \\
\hline Technology & 2012 & 2 & 188,000 & $11,482,801$ \\
\hline Total & & 264 & $1,989,334,759$ & $1,866,490,944$ \\
\hline
\end{tabular}

To compare the difference in the total number of shares repurchased during the test period between a general and specific repurchase, it was noted that the difference amounts to $122,843,815$ shares. Table 3 below presents the JSE sectors that have been the most active in repurchasing their shares during the test period based on the number of announcements. This Table is shown to provide context in relation to the sector and total number of shares repurchased over the test period.

Table 3. Distribution of JSE sectors that repurchased shares

\begin{tabular}{|l|c|c|}
\hline \multicolumn{1}{|c|}{ Sector } & Total number of shares repurchased & Number of announcements \\
\hline Industrial goods \& services & $443,209,049$ & 62 \\
\hline Financial services & $138,773,415$ & 25 \\
\hline Basic resources & $466,414,988$ & 21 \\
\hline Retail & $250,653,155$ & 20 \\
\hline Insurance & $666,905,817$ & 18 \\
\hline Personal \& household goods & $70,023,994$ & 17 \\
\hline Construction \& materials & $170,071,565$ & 16 \\
\hline Technology & $46,455,947$ & 14 \\
\hline Investment instruments & $404,637,279$ & 11 \\
\hline Banks & $29,048,505$ & 11 \\
\hline
\end{tabular}


Table 3 (cont.). Distribution of JSE sectors that repurchased shares

\begin{tabular}{|l|c|c|}
\hline \multicolumn{1}{|c|}{ Sector } & Total number of shares repurchased & Number of announcements \\
\hline Telecommunications & $358,674,936$ & 9 \\
\hline Healthcare & $640,259,646$ & 8 \\
\hline Real estate & $39,721,862$ & 7 \\
\hline Food \& beverage & $17,499,385$ & 5 \\
\hline Travel \& leisure & 448,520 & 4 \\
\hline Media & $14,981,207$ & 3 \\
\hline Chemicals & $4,165,750$ & 2 \\
\hline Oil \& gas & $91,611,477$ & 2 \\
\hline Consumer services & $2,166,705$ & 2 \\
\hline Debt & 102,500 & 264 \\
\hline Total & $3,855,825,702$ & \\
\hline
\end{tabular}

It was noted in Table 3 that the industrial goods and services sector rank highest with the most number of announcements. The financial services sector made the second highest number of share repurchase announcements and consisted of asset managers, investment services firms, speciality finance and consumer finance firms. The basic resources sector made the third highest number of share repurchase announcements. It was also found that the industrial goods and services sector has made the highest number of share repurchase announcements but the insurance sector repurchased the largest number of shares in the test period, followed by healthcare and basic resources sectors.

In comparison to Table 3 above, the JSE sectors in the final sample that have been the most active in repurchasing their shares during the test period based on the number of announcements is shown in Table 4 below. The table is ranked based on the number of repurchase announcements in the final sample. The difference in the type of announcements is indicated to show which sectors perform more 'general share repurchases than a 'specific' share repurchases.

Table 4. Number of repurchase announcements in final sample per sector

\begin{tabular}{|l|c|c|c|}
\hline \multicolumn{1}{|c|}{ Sector } & Number of shares repurchased & Number of general announcements & Difference in type of announcements \\
\hline Industrial goods \& services & $163,001,072$ & 37 & 25 \\
\hline Financial services & $108,753,241$ & 20 & 5 \\
\hline Retail & $172,214,871$ & 13 & 4 \\
\hline Construction \& materials & $113,753,413$ & 12 & 5 \\
\hline Personal \& household goods & $50,583,367$ & 12 & 10 \\
\hline Basic resources & $259,553,965$ & 11 & 4 \\
\hline Technology & $21,558,145$ & 10 & 1 \\
\hline Banks & $19,099,138$ & 10 & 11 \\
\hline Insurance & $459,715,432$ & 7 & 3 \\
\hline Telecommunications & $23,303,873$ & 6 & 2 \\
\hline Food \& beverage & $16,531,280$ & 6 & 7 \\
\hline Real estate & $39,355,412$ & 5 & 0 \\
\hline Investment Instruments & $21,576,667$ & 4 & 5 \\
\hline Media & $14,981,207$ & 4 & 0 \\
\hline Healthcare & $130,312,734$ & 3 & 3 \\
\hline Consumer services & $2,166,705$ & 2 & 0 \\
\hline Travel \& leisure & 436,849 & 2 & 2 \\
\hline Debt & 102,500 & 2 & 2 \\
\hline Chemicals & $1,895,592$ & 1 & 97 \\
\hline Oil \& gas & 0 & 0 & \\
\hline Totals & $1,618,895,463$ & 167 & \\
\hline
\end{tabular}

The following Section provides the findings and discussions based on the three research questions.

Research Question 1: Are there abnormal returns associated with share repurchase announcements on the JSE?
Figure 1 below shows the graph of the daily Cumulative Abnormal average Return for the final sample. The graph indicates that from days $(\mathrm{t}-20)$ to (t-16) before the repurchase announcement, the share prices where trending downwards with a slight recovery on day (t-15). Share prices stabilized for a 
few days further until day (t-7) after which the share prices trend upwards until day $(\mathrm{t}-3)$. The graph shows a second decline from days $(t-3)$ to the event day ( $t 0)$ after which there is a steep increase in the share price until day $(t+7)$. Another decline is observed until day (t-9) after which there is a gradual upward trend of the share price until the end of the event window $(t+20)$.

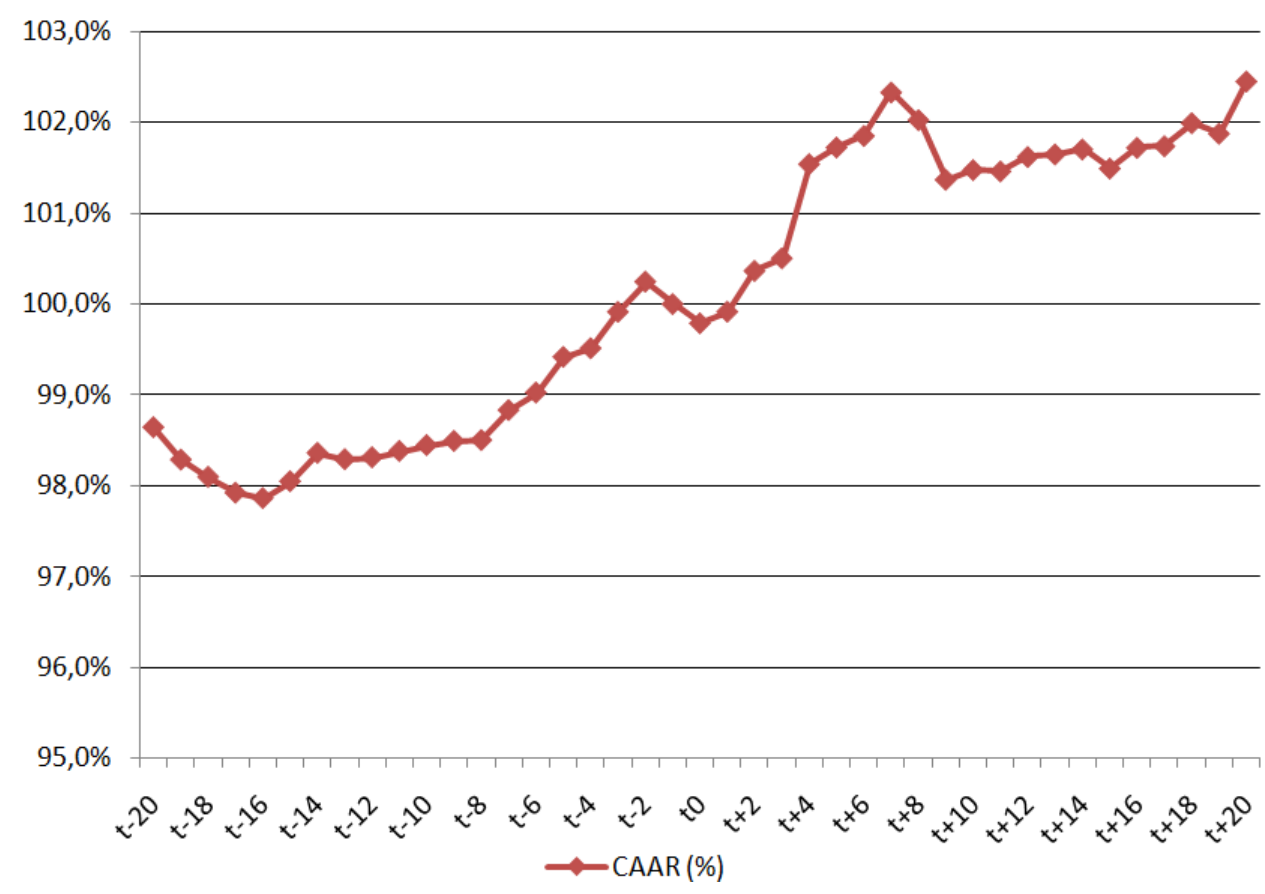

Fig. 1. Daily CAAR for the final sample

The results from the graph above indicate an observable trend of price increase from the announcement day ( $t 0$ ). The result is, therefore, consistent with the signalling theory and "announcement effect" that share repurchase announcements are associated with positive returns.

A parallel comparison of the daily AAR and CAAR analysis throughout the event window, with day 0 as the event day, defined as the day a share repurchase announcement was made. A $100 \%$ benchmark parameter was set on day (t-1) which was used to measure the CAAR from the announcement day (t 0 ) to the end of the event window $(t+20)$.

Further analysis of the results indicated that the difference in the CAAR for the event period ( $\mathrm{t}-20$, $t+20)$ was $3.81 \%$ and the difference in the AAR for $(\mathrm{t}-20, \mathrm{t}+20)$ was $0.46 \%$. This indicates a positive return during the event period. Although the AAR on day ( $\mathrm{t} 0$ ) was negative, indicating that on the day of the announcement, the market reacted negatively, we observed that there was a positive reaction noted for the CAAR and AAR in the period $(\mathrm{t} 0, \mathrm{t}+2)=$ $0.51 \%$ and $0.66 \%$, respectively. The difference in the CAR for the event period $(\mathrm{t}-20, \mathrm{t}+20)$ was $1.42 \%$ and for $(\mathrm{t} 0, \mathrm{t}+2)$ was $1.18 \%$.

The results indicated that share repurchase announcements are associated with positive AARs and CAARs $(0.46 \%$ and $3.81 \%$, respectively) over the event period $(t-20, t+20)$. As a result this indicates that there was a higher gain in relation to the benchmark which provides support that an "announcement effect" exists, thereby supporting the findings of Isa et al. (2011) and Lin et al. (2011) who noted positive differences in the CAR $(1.44 \%$ and $0.52 \%$, respectively) for the event period $(t-20, t+20)$.

Panel A in Table 5 below shows a summarized version on the parallel comparison of the daily AAR and CAAR analysis throughout the event window. A $100 \%$ benchmark parameter is set on day $(t-1)$ which was used to measure the CAAR from the announcement day ( $t$ ) to the end of the event window $(t+20)$. Panel $B$ in the table below indicates that the difference in the CAAR and AAR for the event period $(t-20, t+20$. This indicates a positive return during the event period. Although the AAR on day ( $\mathrm{t} 0$ ) is negative indicating that on the day of the announcement, the market reacted negatively.

Table 5. Daily AAR and CAAR for the final sample

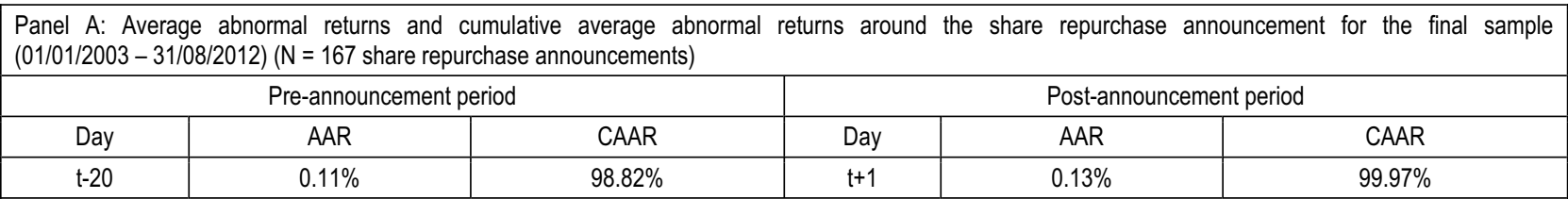


Table 5 (cont.). Daily AAR and CAAR for the final sample

\begin{tabular}{|c|c|c|c|c|c|}
\hline $\begin{array}{l}\text { Panel A: } \\
(01 / 01 / 2003\end{array}$ & $\begin{array}{l}\text { nal returr } \\
N=167 \mathrm{~s}\end{array}$ & $\begin{array}{l}\text { average a } \\
\text { ouncements }\end{array}$ & & rep & for the \\
\hline & re-annour & & & Post-an & \\
\hline Day & AAR & CAAR & Day & AAR & CAAR \\
\hline$t-19$ & $-0.36 \%$ & $98.46 \%$ & $t+2$ & $0.45 \%$ & $100.43 \%$ \\
\hline$t-18$ & $-0.19 \%$ & $98.36 \%$ & $t+3$ & $0.14 \%$ & $100.64 \%$ \\
\hline $\mathrm{t}-17$ & $-0.18 \%$ & $98.10 \%$ & $t+4$ & $1.03 \%$ & $101.49 \%$ \\
\hline $\mathrm{t}-16$ & $-0.06 \%$ & $98.04 \%$ & $t+5$ & $0.18 \%$ & $101.68 \%$ \\
\hline$t-15$ & $0.19 \%$ & $98.22 \%$ & $t+6$ & $0.13 \%$ & $101.81 \%$ \\
\hline$t-14$ & $0.32 \%$ & $98.54 \%$ & $t+7$ & $0.47 \%$ & $102.23 \%$ \\
\hline$t-13$ & $-0.07 \%$ & $98.73 \%$ & $t+8$ & $-0.30 \%$ & $102.07 \%$ \\
\hline$t-12$ & $0.02 \%$ & $98.75 \%$ & $t+9$ & $-0.64 \%$ & $101.40 \%$ \\
\hline$t-11$ & $0.07 \%$ & $98.81 \%$ & $t+10$ & $0.11 \%$ & $101.50 \%$ \\
\hline$t-10$ & $0.07 \%$ & $98.87 \%$ & $t+11$ & $-0.02 \%$ & $101.55 \%$ \\
\hline$t-9$ & $0.05 \%$ & $98.84 \%$ & $t+12$ & $0.16 \%$ & $101.71 \%$ \\
\hline$t-8$ & $0.01 \%$ & $98.85 \%$ & $t+13$ & $0.03 \%$ & $101.74 \%$ \\
\hline $\mathrm{t}-7$ & $0.34 \%$ & $99.19 \%$ & $t+14$ & $0.05 \%$ & $101.86 \%$ \\
\hline$t-6$ & $0.20 \%$ & $99.40 \%$ & $t+15$ & $-0.21 \%$ & $101.65 \%$ \\
\hline$t-5$ & $0.40 \%$ & $99.50 \%$ & $t+16$ & $0.22 \%$ & $101.88 \%$ \\
\hline $\mathrm{t}-4$ & $0.10 \%$ & $99.52 \%$ & $t+17$ & $0.02 \%$ & $101.90 \%$ \\
\hline$t-3$ & $0.40 \%$ & $99.92 \%$ & $t+18$ & $0.25 \%$ & $102.08 \%$ \\
\hline$t-2$ & $0.33 \%$ & $100.25 \%$ & $t+19$ & $-0.11 \%$ & $102.04 \%$ \\
\hline $\mathrm{t}-1$ & $-0.25 \%$ & $100.00 \%^{*}$ & $t+20$ & $0.56 \%$ & $102.62 \%$ \\
\hline to & $-0.21 \%$ & $99.92 \%$ & & & \\
\hline Panel B: AA & er differen & & & & \\
\hline & Eve & & & & CAAR \\
\hline & & & & & $0.51 \%$ \\
\hline & & & & & $3.81 \%$ \\
\hline
\end{tabular}

Note: *denotes the $100 \%$ benchmark parameter used to measure the announcement effect from $\mathrm{t} 0$.

The results of this section supported the studies conducted by Lin et al. (2011) for the "announcement effect" stating that share repurchase announcements cause a significantly positive response from the market. The findings are also consistent with the signalling theory by Grullon and Ikenberry (2000) which states that repurchase announcements are intended to convey a positive signal, indicating that management has correctly forecasted future cash flow and does not need the excess cash to cover future commitments such as capital expenditures or interest payments. Another important feature of the results is the continuation of the price increase for several days after the event. Isa et al. (2011) who conducted an event study on share repurchases of Malaysian firms also found a continuation of price increase for days after the event. Isa et al. (2011) point out that, traditionally, this observation of a price increase after the event is seen to be inconsistent with the notion of an efficient market, however, it may be interpreted as being due to the market reaction of subsequent repurchase announcements made by the company.
In summary, the data analyzed revealed that share repurchase announcements are associated with positive abnormal returns. The results, therefore, provide support for the "announcement effect" and signalling theory.

Research Question 2: Is there a significant price effect in the pre-announcement period?

$\mathrm{H}_{0}$ : There is no significant difference between the means of the AAR in the post-announcement period and pre-announcement period.

$\mathrm{H}_{1}$ : There is a significant difference between the means of the AAR in the post-announcement period and pre-announcement period.

It was clear that in the pre-announcement period, AARs are loosely distributed around the mean of $0.07 \%$. In the post-announcement period, AARs are tightly concentrated around mean of $0.13 \%$ as depicted in Table 6. This indicates that there was a price effect in the post-announcement period that is stronger than in the pre-announcement period.

Table 6. Paired samples statistics

\begin{tabular}{|l|l|c|c|c|c|}
\hline & & Mean & N & Std. deviation & Std. error mean \\
\hline \multirow{2}{*}{ Pair 1 } & AARs - Post & 0.0132 & 20 & 0.003444 & 0.000770 \\
\cline { 2 - 6 } & AARs - Pre & 0.00074 & 20 & 0.002190 & 0.000490 \\
\hline
\end{tabular}


The table below shows the results of the paired samples $t$-test.

Table 7. Paired samples test

\begin{tabular}{|c|c|c|c|c|c|c|c|c|}
\hline \multicolumn{9}{|c|}{ Paired samples test } \\
\hline & \multicolumn{5}{|c|}{ Paired differences } & \multirow{3}{*}{$t$} & \multirow{3}{*}{ Df } & \multirow{3}{*}{$p$-value } \\
\hline & \multirow{2}{*}{ Mean } & \multirow{2}{*}{ Std. deviation } & \multirow{2}{*}{ Std. error mean } & \multicolumn{2}{|c|}{$95 \%$ confidence interval of the difference } & & & \\
\hline & & & & Lower & Upper & & & \\
\hline $\begin{array}{l}\text { Pair } 1 \text { (AARs - Post) - } \\
\text { (AARs - Pre) }\end{array}$ & 0.000584 & 0.004544 & 0.001016 & -0.001542 & 0.002711 & -0.575 & 19 & 0.572 \\
\hline
\end{tabular}

Using the paired sample test (see Table 7) the test resulted in a $p$-value of 0.572 which indicates that the sample evidence is statistically not significant at the $5 \%$ level. The data provide evidence that the null hypothesis $\left(\mathrm{H}_{0}\right)$ cannot be rejected. Thus, a decline in share price has no significant difference when comparing to the post-announcement period.

By testing the means in both periods, we found that the mean AAR in the pre-announcement period was lower than the mean in the post-announcement period, indicating the existent of a "price effect". A paired sample $t$-test was conducted to determine the significance level of the two data sets. The prespecified significance level of alpha $(\alpha)=0.05$ and a higher $p$-value $=0.572$, revealed that there was insufficient evidence to conclude in favor of the alternative hypothesis. The return in the preannouncement period was noted as $-0.20 \%$ while the $t$-value $=0.575$.

In summary, the data analyzed provided evidence in support of the null hypothesis which states that there was no significant difference between the means of the Average Abnormal Return (AAR) in the postannouncement period and pre-announcement period. This indicated that there was no significant "price effect" in the pre-announcement period. Although we found some evidence of a "price effect", the results indicate that it is not significant at the 5\% level. The results of this section provided support to the findings of Yook (2010) who also found that firms that make share repurchase announcements did not experience a "price effect".

Research Question 3: Do firms display market timing ability when repurchasing their shares?

$\mathrm{H}_{0}$ : There is no significant difference in timing share repurchase announcements.

$\mathrm{H}_{1}$ : There is a significant difference in timing a share repurchase announcement.

Examining the trend of general share repurchase announcements during the sample period, it was noted that there has been a decline in the number of share repurchase announcements since its peak of thirty three announcements in 2006. The lowest number of share repurchase announcements, seven, was recorded in 2009. The average number of general repurchase announcements was seventeen.

The distribution of share repurchase announcements during the sample period was analyzed to determine the frequency of announcements per calendar year and for the final sample. Three sub-windows [ $(\mathrm{t}-20$, $t-1),(t 0, t+2),(t 0, t+20)]$ were defined which were used to measure the short-term price performance within the overall event window. A one-sample t-test was used to compare the mean of the final sample AAR in each sub-window to the known value which was the population mean. The prespecified significance level of alpha $(\alpha)=0.05$ and a higher $p$-value for each sub-window $=0.239$, were 0.474 and 0.076 respectively, which revealed that there was insufficient evidence to conclude in favor of the alternative hypothesis. However, further analysis per calendar year revealed support for the alternative hypothesis in 2005, sub-window ( $t$, $\mathrm{t}+20)$ and, in 2010, sub-window ( $0, t+2)$.

These results, thus, suggest that shares in companies making a share repurchase announcement were not significantly under-performing the market. It was also noted that none of the pre-event AARs ( $t-20$, t-1) was significant, although three years (2007, 2009 and 2012) show negative returns within this window period.

The average AAR value for the three day event window ( $0, t+2)$ was $0.14 \%$ which is higher than in the 20 day period $(\mathrm{t}-20, \mathrm{t}-1)$ mentioned above. The $p$ value (0.474) was not significant although further analysis revealed an observable increase in the CAAR during these three days $(\mathrm{t} 0, \mathrm{t}+2)$. In 2010, a $p$-value of 0.005 was noted, indicating evidence of timing the repurchase announcement. However, in the 21-day window $(\mathrm{t} 0, \mathrm{t}+1)$ for 2010 , the average AAR is $0.01 \%$ with a $p$-value of 0.720 , which was not significant.

The 21-day AAR (t $0, \mathrm{t}+20$ ) was $0.12 \%$ with a $p$-value of 0.076 , which was significant. A $p$-value of 0.013 has been noted in 2005 during the 21-day window indicating evidence of timing ability. Table 8 below shows the abnormal share prices surrounding the event day by sub-window and calendar year based on the number of announcements recorded. 
Table 8. Abnormal share price performance surrounding the event day by sub-window and calendar year

\begin{tabular}{|c|c|c|c|c|c|}
\hline \multirow{2}{*}{ Year } & \multirow{2}{*}{ Sample size } & \multirow{2}{*}{ Description } & \multicolumn{3}{|c|}{ Sub-window } \\
\hline & & & $(\mathrm{t}-20, \mathrm{t}-1)$ & $(\mathrm{t} 0, \mathrm{t}+2)$ & $(t 0, t+20)$ \\
\hline \multirow{2}{*}{ Final sample } & \multirow{2}{*}{167} & AAR & $0.07 \%$ & $0.14 \%$ & $0.12 \%$ \\
\hline & & $p$-value & 0.239 & 0.474 & 0.076 \\
\hline \multirow{2}{*}{2003} & \multirow{2}{*}{18} & AAR & $0.14 \%$ & $0.33 \%$ & $0.30 \%$ \\
\hline & & $p$-value & 0.713 & 0.616 & 0.563 \\
\hline \multirow{2}{*}{2004} & \multirow{2}{*}{11} & AAR & $0.02 \%$ & $0.00 \%$ & $0.20 \%$ \\
\hline & & $p$-value & 0.866 & 0.995 & 0.226 \\
\hline \multirow{2}{*}{2005} & \multirow{2}{*}{25} & AAR & $0.12 \%$ & $0.06 \%$ & $0.18 \%$ \\
\hline & & $p$-value & 0.146 & 0.771 & $0.013^{*}$ \\
\hline \multirow{2}{*}{2006} & \multirow{2}{*}{33} & AAR & $0.02 \%$ & $-0.03 \%$ & $0.03 \%$ \\
\hline & & $p$-value & 0.835 & 0.901 & 0.766 \\
\hline \multirow{2}{*}{2007} & \multirow{2}{*}{13} & AAR & $-0.09 \%$ & $0.27 \%$ & $0.11 \%$ \\
\hline & & $p$-value & 0.592 & 0.368 & 0.378 \\
\hline \multirow{2}{*}{2008} & \multirow{2}{*}{16} & AAR & $0.11 \%$ & $-0.04 \%$ & $0.08 \%$ \\
\hline & & $p$-value & 0.441 & 0.926 & 0.565 \\
\hline \multirow{2}{*}{2009} & \multirow{2}{*}{7} & AAR & $-0.08 \%$ & $0.41 \%$ & $0.12 \%$ \\
\hline & & $p$-value & 0.766 & 0.605 & 0.428 \\
\hline \multirow{2}{*}{2010} & \multirow{2}{*}{13} & AAR & $0.07 \%$ & $-0.13 \%$ & $0.01 \%$ \\
\hline & & $p$-value & 0.466 & $0.005^{*}$ & 0.878 \\
\hline \multirow{2}{*}{2011} & \multirow{2}{*}{13} & AAR & $0.18 \%$ & $0.28 \%$ & $0.04 \%$ \\
\hline & & $p$-value & 0.052 & 0.253 & 0.780 \\
\hline \multirow{2}{*}{2012} & \multirow{2}{*}{18} & AAR & $-0.01 \%$ & $0.69 \%$ & $0.18 \%$ \\
\hline & & $p$-value & 0.923 & 0.323 & 0.271 \\
\hline
\end{tabular}

Notes: $*$ denotes that the $p$-value is lower than the significance level alpha $=0.05$, which means that the null hypothesis $\left(\mathrm{H}_{0}\right)$ is rejected and the alternative hypothesis $\left(\mathrm{H}_{1}\right)$ is accepted.

Based on the results in Table 8 , the data provide evidence that the null hypothesis $\left(\mathrm{H}_{0}\right)$ cannot be rejected for the sample as a collective. However, for the sub-windows $(\mathrm{t} 0, \mathrm{t}+20)$ and $(\mathrm{t} 0, \mathrm{t}+2)$ that have been noted in 2005 and 2010, respectively, the null hypothesis $\left(\mathrm{H}_{0}\right)$ can be rejected and the alternative hypothesis $\left(\mathrm{H}_{1}\right)$ can be accepted.

Although some support for the alternative hypothesis was found in the sub-windows for 2005 and 2010, overall, the data indicate that managers do not time their repurchase programs. The support for the alternative hypothesis found in 2005 could be attributed to the upward trend of the market in the boom years rather than pure timing ability. Conversely, support for the alternative hypothesis found in 2010 could be attributed to the recovery years when markets are characterized unstable and volatile returns where managers would be expected to show skill in timing the repurchase programs.

In summary, the analysis of the data indicates that:

1. Consistent with the signalling theory and "announcement effect", share repurchase announcements on the JSE are associated with positive abnormal returns.

2. Although there may be an observable trend of declining prices in the pre-announcement period of a share repurchase, the decline in the share price has no significant difference when compared to the Average Abnormal Return in the post-announcement period.

3. There is no significant difference in timing a share repurchase announcement, indicating that managers do not time their repurchase programs.

\section{Research limitations}

The research focused only on companies listed on the main board of the JSE. The JSE is the only stock exchange in South Arica and is, therefore, the only stock exchange used in this study. The findings may only apply to these companies listed on the main board of the JSE to the exclusion of private companies.

Only the time period from 2003 to 2012 was included in this research. The initial years when share repurchases were allowed on the JSE have been excluded. Therefore, the results of this study are representative of historical periods. Due to availability of the data, the research focused on companies that were listed and remained listed by the end of the test period of 31 August 2012. Companies that have been delisted over the test period for whatever reason were excluded, thus exposing the study to survivorship bias.

\section{Conclusion}

The study examined the existence of an "announcement effect" when a share repurchase announcement is made by a listed companies on the 
JSE. The results indicated that share repurchase announcements are associated with positive Average Abnormal Returns and Cumulative Abnormal Returns over the event period ( $t-20$, $\mathrm{t}+20$ ). As a result this implies that there is a higher gain in relation to the share price before an announcement is made, which is indicative of an "announcement effect" and provides support to the signalling theory. The findings of this South African study is, therefore, consistent with those of similar studies done by Grullon and Ikenberry (2000) on the US market, Isa et al. (2011) on the Malaysian market and Lin et al. (2011) on the Taiwanese market.

The existence of a price effect also investigated to determine if companies that repurchase their shares experience a significant price decline before an announcement was made. Although there was an observable trend of declining prices in the preannouncement period of the event, the decline in the share price was not statistically significant. This result is consistent with Yook (2010) who also found that US firms that make share repurchase announcements did not experience a "price effect".

The results also indicated that there was no significant difference in timing a share repurchase announcement, indicating that managers do not time their repurchase programs which is consistent with Ginglinger and Hamon (2007) who studied French firms.

\section{Implications of the study}

Share repurchases can be used as a tool for stabilising a company's share price that has been following a downward trend. Managers executing a share repurchase program should consider the effects of timing ability to protect the investments of long-term shareholders. Isa et al. (2011) point out that when the market is on an uptrend, there is no necessity for a company to signal under-pricing or make an effort to stabilize the price until there is a long enough period of consecutive declines in the price.

The findings contained in this study may also be used by investors, portfolio managers and share analysts who may regard share purchase announcements as a positive signal. Saville (2012) points out that a share repurchase program demonstrates that a company has surplus cash and that managers see opportunity in their own share. From investor's perspective value, a share repurchase program conveys a very strong signal of a healthy company as it leads to upliftment of financial ratios such as return on equity, price-to-book multiple and future earnings prospects.

\section{Recommendations for future research}

Future research should be conducted on the announcement effect between various industry sectors to determine if the abnormal returns are significantly different. This study can also be expanded to compare the abnormal returns of country specific sectors, for example the abnormal returns of the announcement effect in the South African insurance, industrial goods and services and basic resources sectors, as these were noted to be outliers during the sample period.

Only the time period from 2003 to 2012 was included in this research. The initial years when share repurchases were allowed on the JSE have been excluded. Any future research on share repurchase programs in South Africa should aim to overcome this data constraint by being extended to include the earlier years of data, i.e., 2000, 2001 and 2002.

The period of this study coincides with the boom years of financial markets (2003-2007), the global financial crisis (2008-2009) and the recovery years (2010-2012). This provides a landscape for future studies to test market behavior in relation to share repurchases and examine the market's reaction in each of these periods as a form for robustness check. Isa et al. (2011) point out that this will indicate if the market is consistent in its response to the event regardless of market situations.

\section{Acknowledgement}

The authors wish to acknowledge the invaluable advice of Mr Dechlan Pillay in the subject area, of the University of Pretoria.

\section{References}

1. Asquith, P. \& Mullins, D.W. (1986). Signalling with Dividends, Stock Repurchases, and Equity Issues, Financial Management, 15 (3), pp. 27-44. Retrieved from: http://www.jstor.org/stable/3664842.

2. Bhana, N. (2007). The market reaction to open market share repurchases annoucements: The South African experience, Investment Analysts Journal, 65, pp. 25-36.

3. Blouin, J.L., Raedy, J.S. \& Shackelford, D.A. (2007). Did firms substitute dividends for share repurchases after the 2003 reductions in shareholder tax rates? NBER Working Paper Series.

4. Brockman, P. \& Chung, D.Y. (2001). Managerial timing and corporate liquidity: Evidence from actual share repurchases, Journal of Financial Economics, 61, pp. 417-448.

5. Chan, K., Ikenberry, D. \& Lee, I. (2004). Economic Sources of Gain in Stock Repurchases, Journal of Financial and Quantitative Analysis, 39 (3), pp. 461-479.

6. Chang, S.C., Chen, S.S. \& Chen, L. (2010). Does prior record matter in the wealth effect of open-market share repurchase announcements? International Review of Economics and Finance, 19, pp. 427-435. DOI:10.1016/j.iref.2009.10.015 
7. De Ridder, A. (2009). Share Repurchases and Firm Behavior, International Journal of Theoetical and Applied Finance, 12 (5), pp. 605-631.

8. Dittmar, A.K. (2000). Why Do Firms Repurchase Stock? Journal of Business, 73 (3), pp. 331-355.

9. Ginglinger, E. \& Hamon, J. (2007). Actual share repurchases, timing and liquidity, Journal of Banking \& Finance, 31, pp. 915-938.

10. Grullon, G. \& Ikenberry, D.L. (2000). What do we know about stock repurchases? Journal of Applied Corporate Finance, 13 (1), pp. 31-51.

11. Ikenberry, D.L. \& Vermaelen, T. (1996). The Option to Repurchase Stock, Financial Management, 25 (4), pp. 9-24. Retrieved from: http://www.jstor.org/stable/3665586

12. Ikenberry, D., Lakonishok, J. \& Vermaelen, T. (2000). Stock Repurchases in Canada: Performance and Strategic Trading, Journal of Finance, LV (5), pp. 2373-2397.

13. Isa, M., Ghani, Z. \& Lee, S.-P. (2011). Market reaction to actual share repurchase in Malaysia. Asian Journal of Business and Accounting, 4 (2), pp. 27-46.

14. Jiang, B. \& Koller, T. (2011). Paying back your shareholders, Mckinsey Quarterly.

15. Konchitchki, Y. \& O'Leary, D.E. (2011). Event study methodologies in information systems research. International Journal of Accounting Information Systems, 12, pp. 99-115. DOI:10.1016/j.accinf.2011.01.002

16. Lee, B.-S. \& Rui, O.M. (2007). Time Series Behavior of Share Repurchases and Dividends, Journal of Financial and Quantitative Analysis, 42 (1), pp. 119-142.

17. Lee, C.I., Ejara, D.D. \& Gleason, K.C. (2010). An empirical analysis of European stock repurchases, Journal of Multinational Financial Management, 20, pp. 114-125. DOI:10.1016/j.mulfin.2010.07.002

18. Lemmon, M. \& Zender, J. (2008). Debt capacity and test of capital structure theories.

19. Lin, L.-H., Lin, S.-H. \& Liu, Y.-C.A. (2011). Stock repurchase announcements and stock prices evidence from Taiwan, International Journal of Business and Finance Research, 5 (1), pp. 1-12.

20. Lo, K.-H., Wang, K. \& Yeh, C.-T. (2008). Stock Repurchase and Agency Problems, Emerging Markets Finance \& Trade, 44 (1), pp. 84-94. DOI:10.2753/REE1540-496X440105

21. Mishra, D., Racine, M.D. \& Schmidt, L. (2010). Credibility of corporate announcements and market reaction: Evidence from Canadian share repurchase programs, Canadian Journal of Administrative Sciences, pp. 83-100. DOI:10.1002/CJAS.127

22. Skinner, D.J. (2008). The evolving relation between earnings, dividends and stock repurchases, Journal of Financial Economics, 87 (3), pp. 582-609.

23. Stephens, C.P. \& Weisbach, M.J. (1998). Actual share recaquisitions in open market repurchase programs, Journal of Finance, 53, pp. 313-334.

24. Vermaelen, T. (1981). Common stock repurchases and market signaling: An empirical study, Journal of Financial Economics, 9, pp. 139-183.

25. Von Eije, H. \& Megginson, W.L. (2008). Dividends and share repurchases in the European Union, Journal of Financial Economics, 89 (2), pp. 347-374.

26. Yook, K.C. (2010). Long-run stock performance following stock repurchases, The Quarterly Review of Economics and Finance, 50, pp. 323-331.

27. Zhang, H. (2005). Share price performance following actual share repurchases, Journal of Banking and Finance, 29, pp. 1887-1901. DOI:10.1016/j.jbankfin.2004.06.038. 